Bangladesh J. Bot. 43(1): 65-71, 2014 (June)

\title{
ECONOMIC VALUE ANALYSIS OF GALANTHUS SP. IN TURKEY
}

\author{
Aynur Demir ${ }^{*}$ AND Munevver Arisoy ${ }^{1}$ \\ Department of Environmental Protection and Technology, Aksaray University, Turkey \\ Key words: Economical values, Galanthus sp., Biodiversity, Economic Policy, Turkey
}

\begin{abstract}
The economic value analysis has been carried out by detecting the production, good and service value functions of Galanthus sp. in Turkey. In the analyses, economical valuation techniques, group comparisons, ecological and socio-cultural valuation criteria had been used. Total flow value for goods and service functions of Galanthus sp. had been calculated as \$68/year/unit per Galanthus sp. and the potential flow rate per Galanthus sp. had been estimated at \$137/year. The total value of Galanthus sp. had been calculated as $\$ 544,000,000 /$ year for annual export of 8 million Galanthus. When the positive added value, which was included in ecological and sociological processes and created by non-pecuniary values and the wealth and heritage value were added, it was easily seen that the economic value of the Galanthus was considerably high. Moreover, it had been determined that especially, the medical source value (\$23/year) was a crucial factor among this value.
\end{abstract}

\section{Introduction}

According to the classical economic theory, one of the causes of biological degradation is that goods and services offered by biodiversity are considered as "free goods" and could not be sold or bought in a market which enables the determination of the actual price of biodiversity. The basis of supply and demand theory is, if a good could be supplied "for free", it means that it is demanded and consumed more (Pearce and Moran 1994, Loomis 2000, Freeman 2003). In this frame, as depend on demand, regardless of the population capacity of biodiversity which is in the free of charge category, it is consumed more in relation to the current demand. This situation presents the biodiversity with non-compensable, hardly reversible destruction and at the same time, brings ecological and economical source loss.

Galanthus (snowdrop) species with a crucial position within Turkish geophytes have been drastically affected by degradation. Being a perennial plant with its beautiful flowers coming out in winter and early spring, Galanthus have attracted the attention and appreciation of people and have been used in landscape architecture in parks and gardens especially in Europe. It has also attracted the attention of pharmaceutical industry because of alkaloids such as galanthamin and lectininside in its bulb and in other parts. "Galanthamin" is used for the treatment of serious diseases such as Alzheimer and polio and played a crucial role in increasing demand for pharmaceutical companies of this plant. This situation has commoditized the Galanthus sp. in terms of economy and has made it a "value" causing supply and demand. Galanthus elwesii Hook.f. and G. woronowii Losinsk. (Ekim et al. 2000) especially have great importance in this respect. The increasing demand for Galanthus species has also increased the market supply and thereby threatened Galanthus population. This situation has caused the destruction of "Anatolian nature", which provides habitat for 7 endemic species of Galanthus (Ozhatay 2002, Ozhatay et al. 2005a).

In spite of this damage, Galanthus is commercially commoditised with supply-demand function in the market. It is apparent that Galanthus's functions such as production, ecosystem, habitat and gene source, do not reflect the actual values and those values do not cover Galanthus

*Author for correspondence. <aynurdemir1@yahoo.com>. ${ }^{1}$ Department of Biotechnolog, Faculty of Health Sciences, Ankara University-Turkey. 
destruction for mentioned functions and gene source. Galanthus, which decorates plateaus and the high mountain slopes with its natural beauty, is an important part of our biological richness, genetic and biotechnological resource and a raw material for the pharmaceutical industry. These features of Galanthus show that the "actual value" will be high ecologically and economically.

In the present study, "total economic value of Galanthus" has been assessed by determining the production, goods and service functions of G. elwesii and G. woronowii by means of consumption and non-consumption value criteria. In the valuation study, first of all, it is detected that snowdrop has a market value in the market depending on the supply-demand relation. Then, the flow value of Galanthus production, goods, and service functions had been estimated within the scope of the market value by using economic valuation techniques. Such studies to estimate the total economic value of the plant genetic resources' production, goods, and service functions will play a crucial role in the effective use of biological resources. This will create awareness on the sustainable use of biological resources for countries having rich biodiversity.

\section{Materials and Methods}

Evaluation of a survey questionnaire was carried out with 21 expert participants working on Galanthus from Antalya, Ankara, Yalova, Trabzon, Karaman, Izmir and Istanbul in Turkey. The semi-configured interview form was used for this research. Value functions of Galanthus, in accordance with Costanza et al. (1997), Nunnes et al. (2000), De Groot et al. (2002) and using data obtained from field research had been explained in 7 main categories such as production, and information function values and habitat, ecosystem and option, asset and bequest values (Table 1). These categories had also been represented in subcategories. In this analysis, by using economic value approach, group comparison, ecological value and socio-cultural value approaches developed by adopting from Costanza et al. (1997), Nunes et al. (2000), De Groot et al. (2002), De Groot (2006), quantitative and qualitative value analyses of snowdrops' production, goods and services had been made (Table 1).

Table 1. Matrix of quantitative and qualitative evaluation of Galanthus sp.*

\begin{tabular}{|c|c|c|c|c|}
\hline \multirow{2}{*}{$\begin{array}{l}\text { Galanthus function } \\
\text { (value) }\end{array}$} & \multicolumn{3}{|c|}{ Quantitative evaluation $^{1}$} & \multirow{2}{*}{$\begin{array}{l}\text { Qualitative } \\
\text { evaluation }^{5}\end{array}$} \\
\hline & $\begin{array}{l}\text { Direct market } \\
\text { analyses }^{2}\end{array}$ & $\begin{array}{l}\text { Protection } \\
\text { cost }^{3}\end{array}$ & $\begin{array}{c}\text { Production } \\
\text { function income }\end{array}$ & \\
\hline \multicolumn{5}{|l|}{ 1. Production } \\
\hline Production income & $x^{6}$ & & $x$ & \\
\hline Usage value in biotechnology & & & & $x$ \\
\hline Pharmaceutical resource & $x$ & & $x$ & \\
\hline \multicolumn{5}{|l|}{ Usage in traditional medicine } \\
\hline Commercial resource & $x$ & & $x$ & \\
\hline Ornamental plant usage & $x$ & & $x$ & \\
\hline \multicolumn{5}{|l|}{ 2. Information function } \\
\hline Aesthetical & & & & $x$ \\
\hline Cultural & & & & $x$ \\
\hline Historical and artistic & & & & $x$ \\
\hline Scientific and educational usage & & & & $x$ \\
\hline Eco-tourism & & & & $x$ \\
\hline \multicolumn{5}{|l|}{ 3. Habitat } \\
\hline Biodiversity & & & & $x$ \\
\hline Endemic diversity & & & & $x$ \\
\hline Protection & & $x$ & & \\
\hline
\end{tabular}


(Contd.)

\begin{tabular}{|c|c|c|c|c|}
\hline \multicolumn{5}{|l|}{ 4. Ecosystem } \\
\hline Matter (Gas) cycle & & & & $x$ \\
\hline Nutrient cycle & $x$ & - & $x$ & \\
\hline Pollination & $x$ & - & $x$ & \\
\hline 5. Option & $x$ & - & - & \\
\hline 6. Asset & & & & $x$ \\
\hline 7. Bequest & & & & $x$ \\
\hline
\end{tabular}

*Adopted from Costanza et al. 1997. Nunes et al. 2000, De Groot et al. 2002.

${ }^{1}$ Quantitative evaluation: In quantitative evaluation, snowdrop functions are displayed as currency. In international literature this is reflected as USA $\$$ ha/year. In this study, it has been evaluated as USA $\$ /$ unit/year $(1$ USA $\$=1,70$ TL).

${ }^{2}$ Direct market analyses: This is based on direct monetary value generated from market, because snowdrop is a good that could be sold and bought from markets.

${ }^{3}$ Protection cost: This includes protection cost of snowdrops and maintenance of this protection measures.

${ }^{4}$ Production function income: Protection functions represent the contribution of snowdrop to individual income.

${ }^{5}$ Qualitative Evaluation: Quantitative evaluation is used for determining specific ecological criteria such as snowdrop's ecosystem value, information function etc.

$6 " \times "$, shows that the preferred method in determination of the Galanthus service function.

In economic value approach, the market price method, the production function income method and the method of protection cost of snowdrop had been considered (Costanza et al. 1997, Nunes et al. 2000, De Grood et al. 2002). In group comparisons, the data obtained from similar studies carried out else where had been used. The ecological value analysis and the production and trade of bulbs of Galanthus were also carried out (Ozhatay et al. 2005b, Ekim et al. 2000, Kantarlri 2006, TUGEM 2004-2012). In socio-cultural evaluation approach (De Groot 2006), the contributions of Galanthus to cultural wealth, the historical and artistic accumulation of people, ecotourism, science and education have been evaluated by considering the compassion, care and emotional bonds formed between Galanthus sp. and human. The potential economic value was calculated by considering 10 years time period and applying $10 \%$ discount rate to the current value of the Galanthus (Eq. 1) (Ozsabuncuoglu and Ugur 2005).

$$
\mathrm{PV}_{\mathrm{t}}=\mathrm{NR}_{\mathrm{t}} /(1+\mathrm{i})^{\mathrm{t}} \quad \text { (Eq. 1) }
$$

where, $\mathrm{PV}_{\mathrm{t}}=$ current value of income of $\mathrm{t}$ year, $\mathrm{NR}_{\mathrm{t}}=$ net profit obtained in $\mathrm{t}$ year, $\mathrm{i}=$ discount ratio and $\mathrm{t}=$ time expression.

\section{Results and Discussion}

For G. elwesii and G. woronowii production, goods and service value functions' total economic value oriented to measurable benefits was estimated at $\$ 68$ for a unit Galanthus sp. per year and the potential economic value was estimated as annually $\$ 137$ (Table 2). Total flow value for Galanthus has been calculated as $\$ 544,000,000 /$ year for annual export of 8 million Galanthus sp. and total potential value had been calculated as $\$ 10,960,000,000 /$ year. This estimated value is a 1000 -fold higher than $\$ 532,774 /$ year, which is the annual export income of Galanthus. When the positive added value, which was included in ecological and socio-cultural processes (not expressed materially) and the wealth value were added, it was easily seen that the economic value of the Galanthus was considerably high.

The production income value for each unit Galanthus bulb within the total economic value of Galanthus sp. was estimated at $\$ 0.04$ year (Table 2). This value was $\$ 320,000 /$ year for 8 million Galanthus sp. and on the other hand, the household income was nearly $\$ 320 /$ year per each household. However, Lee (2002) revealed that the production income for orchid (Phalaenopsis 
sp.) for farmer was approximately $\$ 113,000 /$ year under protection facilities in Taiwan. In Taiwan, the production income supplied from intensive orchid production obtained by the use of biotechnology the capital was quite high. Whereas, in Turkey, when the per capita income in gross national product and Turkey's biodiversity richness are considered, it could clearly be seen that Galanthus production income is low. If the Galanthus, the potential raw material of modern biotechnology, were grown by biotechnological methods in Turkey, there would be an increase in the production income of households. In this situation, the increase in the Galanthus production would also cause an increase in all Galanthus flow values and that would create positive added value.

Table 2. Qualitative and quantitative economic value of Galanthus spp.

\begin{tabular}{|c|c|c|c|}
\hline \multirow[b]{2}{*}{$\begin{array}{l}\text { Galanthus function } \\
\text { (value) }\end{array}$} & \multicolumn{2}{|c|}{ Economic value } & \multirow[b]{2}{*}{$\begin{array}{c}\text { Comparison value } \\
\text { (US \$) }\end{array}$} \\
\hline & $\begin{array}{c}\text { Economic } \\
\text { value } \\
\text { (US \$/unit/year) }\end{array}$ & $\begin{array}{c}\text { Potential } \\
\text { economic value } \\
\text { (US \$/unit year) }\end{array}$ & \\
\hline \multicolumn{4}{|l|}{ Production } \\
\hline Production income & 0.04 & 0.13 & 0.113 million/year (Lee 2002) \\
\hline Usage in biotechnology & +++ & +++ & 50 million/year (Costanza et al. 1997) \\
\hline Medical resource & 23 & 31.8 & 290 million/unit/year (Kumar 2004) \\
\hline $\begin{array}{l}\text { Usage in traditional } \\
\text { medicine }\end{array}$ & 0.002 & 0.003 & 3 million/unit/year (Bhagirathy 2003) \\
\hline Commercial source & 2.1 & 4.1 & $4 / \mathrm{kg} /$ year (Bann and Clemens 1999) \\
\hline Ornamental plant & 1 & 2.77 & 3-145/ha/year (De Groot et al. 2002) \\
\hline \multicolumn{4}{|l|}{ Information } \\
\hline Aesthetical & +++ & +++ & 7-1760/ha/year (De Groot et al. 2002) \\
\hline Cultural & +++ & +++ & 7-145/ha/year (Costanza et al. 1997) \\
\hline Historical and artistic & +++ & +++ & 1-25/ha/year (De Groot et al. 2002) \\
\hline $\begin{array}{l}\text { Scientific and educational } \\
\text { usage }\end{array}$ & +++ & +++ & \\
\hline Eco-tourism & + & ++ & 2-6000/ha/year (De Groot et al. 2002) \\
\hline \multicolumn{4}{|l|}{ Habitat } \\
\hline Biodiversity & +++ & +++ & \\
\hline Endemic diversity & +++ & +++ & \\
\hline Protection & 37.71 & 95.21 & $\begin{array}{l}\text { 7/for each household person/year- } \\
\text { 704/year (Erdem 2004) }\end{array}$ \\
\hline \multicolumn{4}{|l|}{ Ecosystem } \\
\hline Matter (gas) cycle & ++ & ++ & $\begin{array}{l}87-21100 / \text { ha/year (De Groot et al. } \\
2002)\end{array}$ \\
\hline Nutrient cycle & 1.7 & 2.5 & $87-21100 /$ ha/year (De Groot et al. 2002) \\
\hline *Pollination & 2 & 3 & 62 /ha/year (Eardley et al. 2006) \\
\hline Option (pharmaceutical) & 0.022 & 0.03 & $\begin{array}{l}1575 / 9 \text { thousand/year (Bann and } \\
\text { Clemens 1999) }\end{array}$ \\
\hline Asset & +++ & +++ & 703/ha/year (Auroba 2007) \\
\hline Bequest & +++ & +++ & \\
\hline Total & 68 & 137 & \\
\hline
\end{tabular}

+ (less valuable), ++ (medium level valuable), +++ (very valuable).

*Pollination value represents the germination value of the Galanthus seeds spreading via ants and environmental factors. 
In the analyses, it has been detected that the medical value of Galanthus is an important value component. For unit Galanthus, medical resource value had been estimated at $\$ 23$ /year. For 8 million Galanthus bulbs, the market price had been estimated to $\$ 184,000,000 /$ year. The present research indicates that the potential value of Turkey's diversity is higher in comparison with researches conducted in other countries. For instance, in the USA 16 out of 5000 plants, had medical source value and each of them had \$ 203 million worth (Fransworth and Soejarto 1985, Kumar 2004). According to the same research, Principe (1989) indicated that in 1985, prescription value of 40 plants in the USA was $\$ 11.7$ million and the value of each plant was estimated at approximately \$290 million (Kumar 2004). When the market medical change value of the snowdrop was compared to this datum, it is obvious that its value was not low at all.

Another essential parameter within the estimated total value is the protection value. The total annual value of the estimated in situ and ex situ protection for a unit Galanthus is $\$ 37.71$ and potential protection value was estimated at $\$ 95.21 /$ year for a unit Galanthus sp. When the protection project incomes are considered, the estimated protection value was annually $\$ 301,680,000$ for 8 million Galanthus bulbs. Out of 13 species 7 endemic species of Galanthus grow in Turkey and 34 out of 122 SPA categorized according to IUNC (the International Union for Conservation of Nature) categories sprouts in Turkey indicate high biologic and endemic diversity value of Galanthus (Ozhatay et. al. 2005a,b). The evaluation of these habitats mentioned above as special protection fields played an important role in increasing the protection value of Galanthus. In addition, the fact that Galanthus species listed in CITES annex II and are commercially protected by regulation of "Production and Commerce of Turkey Natural Flower Bulb" is another factor raising the protection value. In Turkey, only two Galanthus species Galanthus elwesii and G. woronowii - are allowed for trade within the quota, and commercial value for a Galanthus bulb is estimated at $\$ 2.1 /$ year. In European markets, these two species' market prices as ornamental plants are $\$ 1 /$ unit/year.

Erdem (2004) determined "wild orchid value", where households willingness to pay was estimated at \$7/year for the protection of orchid in Turkey. In another research conducted by Sattout (2007), in Lebanon aiming to designate Lebanon cedar forests' protection value, household value had been calculated as $\$ 20 /$ year. When these researches were compared to the estimated Galanthus protection value, it was remarkable that the protection value of Galanthus was high and was supported with sustainable economic policies in Turkey. The regulation of its trade within the scope of the regulation on natural flower bulbs with quota, set an important example in terms of global species protection policies, as well as played a role in enhancing the effectiveness of sustainable protection policies.

Research results profound that Galanthus's goods and services flow values were so important in view of ecological processes, as well. These are icrohabitats which are formed via biotic effects within the ecosystem as living areas of several microorganisms and interrelationships, among organisms. Mutual life that is formed among these living groups, provide both continuity of vital and reproduction functions of Galanthus sp. and secures the lives of other living groups by creating nutritional sources for them.

The short life span of snowdrop shortens the contribution of time to material cycle. However, the fact that ants exist in the food chain mutually increases food cycle and reproduction value of snowdrop. In this context, minimum contribution of Galanthus to the food cycle was $\$ 1.7 \$$ year and germination values of snowdrop bulbs spreading via ants and natural conditions were $\$ 2 /$ year. For 8 million Galanthus bulbs, these values were $\$ 13.6$ million/year and \$16/year, respectively. Here, ants are master gardeners for Galanthus sp. De Groot et al. (2002) stated that the value of contribution of natural and semi natural ecosystems to the food cycle was $\$ 7-211.00 /$ ha/year. As stated by Eardley et al. (2006), pollination value of coffee growing in 7\% of Costa Rica forests 
estimated as $\$ 62 / \mathrm{ha} /$ year. When evaluated with these data and considered the Galanthus's role in ecological processes, it is obvious that the food cycle and the pollination values of the Galanthus sp. are considerably high and important.

Anatolian people are living among these Galanthus that made this flower an important part of Anatolian culture by establishing emotional bonds with these and by using this flower in historical, cultural and artistic works. This resistant flower, sometimes a motif in architecture, sometimes representing hope in songs and poems appear as an important value parameter in terms of socio-cultural and affects people positively in view of social aspects.

As a result of this economic value analysis, total flow values of Galanthus production, goods and service functions had been estimated for each year as $\$ 68$ for each Galanthus bulb, and the total potential value had been estimated as $\$ 137$ for each year. When socio-cultural values, bequests and asset values evaluated only by qualitative data were added, it was seen that total economic value would increase to a considerable amount rationally and create a positive added value.

Among the mentioned value flows, the medical source values and protection values create important parameters in terms of biological and medical plant richness of Turkey. Turkey has been a very attractive place, especially for pharmaceutical firms and scientists because more than 500 medicinal plants, each being a potential component or raw material for pharmacy, grow in Turkey. This situation increases the potential value of Turkey in terms of plant diversity. As it is evident that the survival and the transfer of Galanthus with high economic value to the next generations with today's conditions is important in terms of sustainability of ecological, economic and sociocultural values. In this study, the results of economic value analysis reveal the true value of Galanthus rationally in economic, ecological and socio-cultural aspects. Furthermore, the research results are crucial in terms of providing sustainability in the production, good and service functions of Galanthus sp. and the development of sustainable policies. It is seen that sustainable conservation policies are developed and applied in Turkey for the preservation of Galanthus wealth and to ensure the maximum benefit from Galanthus production services. With this arrangement, the Galanthus destruction could be minimized by maximizing the benefit regarding Galanthus goods and services.

Moreover, the results of this research are important in protecting biodiversity and endemic diversity on the basis of species. It shows the necessity of considering total economic value into the decision making mechanisms to provide sustainable management. The evaluation of biological sources together with economic processes should be to included in local management plans to adapt relevant policies. Through this, it is possible to provide effective, sustainable utilization of sources and to convey this biological resources to next generations.

\section{References}

KAD (Kuş Arastırma Dernegi) 2007. Yumurtalık Lagunleri Yonetim Planı, in Aruoba C., Yumurtalık Lagunu'de Sosyo- Ekonomik Degerlendirme, Publisher KAD, 58-65, Ankara (in Turkish)

Bann C and ve Clemens M 1999. Forestry sector analyses global overlapping program study final report: forest resources management and minimum values estimation in externalities related benefiting from forestry and related suggestion derived from this data. Ministry of Forestry, World Bank, 37, Ankara.

Bhagirathy KA 2003. Valuation of medicinal plants: unresolved issues and emerging questions. Southasian network for development and environmental economics newsletter, Web acces, 10.10.2008, www.sandeeonline.org/newsletter/downloadable_pdf/newsletter_6.pdf

Costanza R, d'Arge R, d'Groot R, Farber S, Grasso M, Hannon B, Limburg K, Naeem S, O'Neill VR, Paruelo J, Raskin GR, Sutton P and van den Belt M 1997. The value of the world's ecosystem services and natural capital. Nature 387: 253-260. 
De Groot R, Wilson AM and Boumans JMR 2002. A typology for the classification and valuation of ecosystem functions, goods and services. Ecol. Econ. 41: 393-408.

De Groot R 2006. Function-analysis and valuation as a tool to assess land use conflicts in planning for sustainable, multi-functional landscapes. Lands. Urb. Plann.75: 175-186.

Eardley C, Roth D, Clarke J, Buchmann S. and Gemmill B 2006. Pollinators and pollination: A resource book for policy and practice. African Pollinator Initiative (API), 16, 11, US

Ekim T, Koyuncu M, Vural M, Duman H, Aytaç Z and Adıgüzel N 2000.Turkish plants red book. Turkish Nature Protection Foundation Publications, Ankara.

Erdem EH 2004. Economical value of biodiversity determination: wild orchid example, Ege University, Institute of Science, Master Thesis, Izmir, Turkey.

Freeman AMIII 2003. The measurement of environmental and resource values; theory and methods. Resources for the Future, Washington D.C.

Farnsworth NR and Soejarto DD 1985. Potential consequences of plant extraction in the United States on the current and future availability of prescription drugs. Econ. Bot. 39(3): 231-240.

Kantarli S 2006. Wildlife trade CITES Turkish nature protection foundation, Ankara. pp.103-110.

Kumar P 2004.Valuation of medicinal plants for pharmaceutical uses. Curr. Sci. 86(7): 930-937.

Lee SC 2002. An economic analysis of orchid production under protected facilities in Taiwan: case of Phalaenopsis. Proc. $1^{\mathrm{s}}$ on Trop. Subtrop. Greenhouses. Eds. Chen S and LIN T-T, Acta Hort. 578: 249255, Taiwan.

Loomis BJ 2000. Can environmental economic valuation techniques aid ecological economics and wildlife conservation? Wildlife Society Bulletin 28(1): 52-60.

Nunes PDLA, Van den Bergh JMJC and Nijkamp P 2000. Ecological-economic analysis and valuationof biodiversity, Tinbergen Institute, Web acces, 02.03.2008, http://www.tinbergen.nl//discussion. papers/00100pdf

Ozhatay N 2002. Diversity of bulbous monocots in Turkey with special reference to chromosome numbers. Pure Appl. Chem. 74(4): 547-555.

Ozhatay N, Ekim T, Oztürk R, Yüzbaşığlu S and Genç I 2005a. Study on protection status of Turkish Geophytes listed in CITES and Continuous Utilizing Opportunities. TUBITAK, Project No: TBAGÇ.SEK/21 (102T107), İstanbul.

Ozhatay N, Byfield A and Atay S 2005b. Turkish 122 important plant areas WWF-Turkish (DoğalHayatıKoruma Vakfi) Publishing, Istanbul.

Ozsabuncuoğlu HIve and Uğur AA 2005. Natural sources economy, management and politics, İmaj Publishing, Ankara. pp. 241.

Pearce D and Moran D 1994. The economics value of biodiversity. Earthscan Publ. Ltd., 4-7, London, UK.

Principe P 1989. The economic value of biodiversity among medicinal plants. Paris: OECD.

Sattout JE, Talhoukb NSO and Caligaria SDP 2007. Analysis of economic value of Cedar relics in Lebanon: An application of contingent valuation method for conservation. Ecol. Econ. 61: 315-322.

TUGEM 2004. Regulation regarding natural flower bulbs extraction, production and trading, T.B.TUGEM, Ankara

TUGEM 2012, Regulation regarding natural flower bulbs extraction, production and trading, T.B.TUGEM, Ankara

(Manuscript received on 11 February, 2013; revised on 13 February, 2014) 